\title{
Effects of Fentanyl and Butorphanol on Induction Dose of Propofol in Adults
}

\author{
Dr.Haobam Sofia ${ }^{1}$, Dr.Maharabam Binarani ${ }^{2}$, Dr. L Deban ${ }^{4}$, \\ Dr. H.Kenedy ${ }^{1}$, Dr.Aditi Bhatacharya ${ }^{1}$, Dr.Y. Arunkumar ${ }^{3}$ \\ ${ }^{l}$ Post Graduate Student,DepartmentOf Anaesthesiology, Regional Institute Of Medical Sciences Imphal,India \\ ${ }^{2}$ Senior Registrar, Department Of Anaesthesiology,Regional Institute Of Medical Sciences Imphal,India \\ ${ }^{3}$ Professor, Department Of Anaesthesiology,Regional Institute Of Medical Sciences Imphal,India \\ ${ }^{4}$ Assistant Professor,DepartmentOf Anaesthesiology, Regional Institute Of Medical Sciences Imphal,India
}

\begin{abstract}
Background: Propofol induction dose is reduced with concomitant use of opioids as a result of a possible synergistic action.

Objective: To study the effects of fentanyl and butorphanol on induction dose of propofol in adults.

Methods: Onetwentypatients of either sex, of ASA(American society of anesthesiologist) I and II, undergoing elective surgery under general anaesthesia was taken and randomly allocated into three groups of 40 each. Group I received intravenous fentanyl $2 \mu \mathrm{g} / \mathrm{kg}$, Group II $20 \mu \mathrm{g} / \mathrm{kg}$ and Group III $40 \mu \mathrm{g} / \mathrm{kg}$ butorphanol. Induction of anaesthesia was done with propofol $(30 \mathrm{mg} / 10 \mathrm{~s})$ till the loss of response to verbal commands. Patients hemodynamic were recorded before administration of study drugs, 5 minutes thereafter, at the time of induction, for $2 \mathrm{~min}$ post-induction and post-intubation for $5 \mathrm{~min}$ at $1 \mathrm{~min}$ interval. The study concluded 5 min after intubation.
\end{abstract}

Results: Fentanyl $2 \mu \mathrm{g} / \mathrm{kg}$ reduces the induction dose of propofol to $1.01 \pm 0.25 \mathrm{mg} / \mathrm{kg}$.Butorphanol $20 \mu \mathrm{g} / \mathrm{kg}$ reduces the induction dose of propofol to $0.95 \pm 0.18 \mathrm{mg} / \mathrm{kg}$ and butorphanol $40 \mu \mathrm{g} / \mathrm{kg}$ to $0.90 \pm 0.15 \mathrm{mg} / \mathrm{kg}$. However, sedation was observed to a greater degree with butorphanol $40 \mu \mathrm{g} / \mathrm{kg}$.

Conclusion:Fentanyl $2 \mu \mathrm{g} / \mathrm{kg}$, butorphanol $20 \mu \mathrm{g} / \mathrm{kg}$ and $40 \mu \mathrm{g} / \mathrm{kg}$ reduces the induction dose of propofol comparably.However butorphanol $40 \mu \mathrm{g} / \mathrm{kg}$ was associated with more sedation.

Keywords: Butorphanol, Fentanyl, Propofol.

\section{Introduction}

Intravenous anaesthetics have become the primary agents for induction of general anaesthesia. Propofol is one of the most popular drugs used in the induction of anaesthesia. It is a rapidly acting intravenous anaesthetic agent with a half life of only around $2 \mathrm{~min}$ and an efficient hepatic and extra hepatic clearance. Recovery from propofol is rapid and clear headed with almost no hangover effect. ${ }^{1}$ Propofol's pharmacokinetic properties and low incidence of nausea and vomiting associated with it makes it particularly useful for short procedures and ambulatory surgery. However, propofol produces significant reduction in systemic vascular resistance and cardiac filling leading to a greater degree of hypotension as compared to other hypnotic agents. ${ }^{2,3}$ The most prominent cardiovascular effect of propofol is a decrease in arterial blood pressure during induction ofanaesthesia. At induction dose, it causes $25 \%$ to $40 \%$ reduction of systolic blood pressure, mean and diastolic blood pressure.

The incidence of cardiorespiratory depression appears to be higher than that of other induction agents. ${ }^{1,2,-6}$ The haemodynamic effects of propofol are magnified in hypovolemic or elderly patients and in patients with impaired left ventricular function. These patients will benefit from a reduced dose of propofol.Thedose of propofolrequired to induce anaesthesia in unpremedicated patients is $2.5 \mathrm{mg} / \mathrm{kg}$. ${ }^{2,3,7} \mathrm{It}$ has been found that the induction dose can be reduced by premedication with an opioid.Fentanyl is a potent opioid agonist which acts at mu receptor. It is 100 times more potent than morphine. It is added during induction of anaesthesia to provide analgesia and to decrease the hypertensive response to intubation ${ }^{10}$.It also potentiates the hypnotic effect of propofol.Butorphanol is an analgesic possessing mixed agonist and antagonist activity at opiate receptor. It is a kappa-receptor agonist and mu-receptor antagonist ${ }^{9}$. Due to its receptor specificity, it has analgesic and sedative properties without causing respiratory depression or dependency. Its most prominent side effect is sedation. Butorphanol has been used as a preoperative sedative and analgesicandas a supplement to balanced anaesthesia. It has also been used for conscious sedation.It is suggested that butorphanol could also be used to reduce the requirement of propofol at induction.

The aim of our study is to compare the propofol induction dose with butorphanol and fentanyl pretreatment, using clinical end-points, and to identify the optimal dose of propofol that would augment the 
hypnotic effect of propofol without causing undue adverse effects such as increased sedation and delayed postoperative recovery.

\section{Materials And Methods}

This study was randomized, prospective, double-blind one, conducted in the Department of Anaesthesiology,aTertiary Care Centre inImphal, Manipur, during October 2014 to September 2016. The "Patients of American Society of Anaesthesiologists (ASA) ${ }^{12}$ physical status I or II, between 18 and 65 years of age, undergoing elective surgery under general anaesthesia were included in the study." Patients with history of cardiac,cardiovascular,respiratory,hepatic or renal disease, allergy to study drugs, risk of regurgitation,predicted difficult airway,obesity and pregnancy, alcohol or opioid abuse,onsedatives, anticonvulsants, antipsychotics and antihypertensives were excluded from the study.

Based on a previous study, ${ }^{3}$ the estimated sample size with an $\alpha$ error of 0.05 and power of $80 \%$ for equivalence of groups was calculated to be 36 in each group, assuming the dose reductions in propofol with the two study drugs to be $20 \%$ and $50 \%$. One twenty patients were recruited for this study. Patients were randomized into one of the following three groups(Group Ireceiving intravenous fentanyl $2 \mu \mathrm{g} / \mathrm{kg}$, Group IIreceiving butorphanol $20 \mu \mathrm{g} / \mathrm{kg}$ and Group IIIreceiving butorphanol40 $\mu \mathrm{g} / \mathrm{kg}$ ) on the basis of a computergenerated random number table. After obtaining approval for conducting the study from the institutional ethics committee, patients scheduled for elective surgery under general anaesthesia and fulfilling the inclusion criteria were explained about the purpose and procedure of the study and enrolled after getting written informed consent. The enrolled patients were kept fasting for 8 hours and they were not administered any sedative as premedication on the day of surgery. An intravenous line was secured in a peripheral vein. The baseline heart rate(HR), systolic blood pressure (SBP), diastolic blood pressure (DBP), mean arterial pressure (MAP), respiratory rate $(\mathrm{RR})$ and oxygen saturation $\left(\mathrm{SpO}_{2}\right)$ wererecorded.The drugs were prepared in identical syringes and in equal volume by an anaesthesiologist and another anaesthesiologist who was blinded to the study drugadministered the drugs.

After administration of the study drug, the patient remains undisturbed for $5 \mathrm{~min}$. The sedation level was then assessed using the observer's assessment of alertness scale(OAA/S). ${ }^{13}$ Patient were observed for nausea, vomiting, pruritis, $\mathrm{RR}<8 \mathrm{~min}$, and $\mathrm{SpO}_{2}<90 \%$. Anaesthesia was induced with propofol $(30 \mathrm{mg} / 10 \mathrm{sec})$ using a syringe pump till the loss of response to verbal commands. The anaesthesiologist performing the clinical observations was blinded to the study drug administered. Subsequent muscle relaxation was achieved with rocuronium $1 \mathrm{mg} / \mathrm{kg}$. The patient's lungs were manually ventilated with $100 \% \mathrm{O}_{2}$ for 2 min before endotracheal intubation. Following intubation, anaesthesia was maintained with $1 \%$ isoflurane in oxygen: nitrous oxide (35\%:65\%). Patient was not given any stimulation for $5 \mathrm{~min}$ after intubation. The HR, SBP,DBPand MAP were recorded before administration of study drugs, 5 minutes thereafter, at the time of induction, for 2 min postinduction and post-intubation for $5 \mathrm{~min}$ at $1 \mathrm{~min}$ interval.The study concluded $5 \mathrm{~min}$ after intubation. The data collected were entered in a computer and statistical analysis was performed using Statistical Pakage for Social Sciences (SPSS-version 20, Chicago, IL, USA).Numerical /continuous variables were presented as Mean \pm SD (standard deviation) and for qualitative/categorical variables were again described as number of cases and percentages. The difference of three means, one each from each group, for each parameter were compared by ANOVA (Analysis of Variance Ratio) test, commonly known as F-test and formultiple comparisons of means, Post Hoc Tests of Bonferroni was advocated whenever applicable. For categorical variables, $\chi^{2}$-test(chi-square) was applied if data permit. However in some table, asmost of the theoretical cell frequencies were found to be either less than 5 or nil the test statistic like $\chi^{2}$ could not be applied and therefore interpretation was made based on percentages only. All comparisons were two-sided and the P-values of $<0.05$ and $<0.01$ was treated as the cut off values for significance and highly significance respectively.

\section{Results}

All the 120 patients completed the study protocol. The patient demographics such as age ,sex ,height and weight were comparable and insignificant $(\mathrm{P}>0.05)$ in the three groups as shown in Table 1.

Table 1:Demographic profile

\begin{tabular}{|c|c|c|c|c|c|}
\hline \multirow[b]{2}{*}{$\begin{array}{l}\text { Para- } \\
\text { Meters }\end{array}$} & \multicolumn{4}{|c|}{ Mean \pm SD } & \multirow[b]{2}{*}{ P-value } \\
\hline & $\begin{array}{l}\text { Group I } \\
\text { (fentanyl } \\
2 \square \text { g/kg) } \\
(\mathbf{n}=\mathbf{4 0})\end{array}$ & $\begin{array}{c}\text { Group II } \\
\text { (butorphanol } \\
\mathbf{2 0} \square \mathrm{g} / \mathbf{k g}) \\
(\mathbf{n}=\mathbf{4 0})\end{array}$ & $\begin{array}{l}\text { Group III } \\
\text { (butorphanol } \\
\mathbf{4 0} \square \mathrm{g} / \mathbf{k g}) \\
(\mathrm{n}=\mathbf{4 0})\end{array}$ & $\begin{array}{l}\text { Total } \\
(\mathrm{n}=120)\end{array}$ & \\
\hline Age(years) & $36.60_{ \pm} 10.51$ & $35.43_{ \pm} 12.85$ & $36.88_{ \pm} 13.05$ & $36.30_{ \pm} 12.11$ & 0.853 \\
\hline Weight(kg) & $55.33_{ \pm}{ }_{ \pm} 9.35$ & $57.30_{ \pm} 8.93$ & $55.45_{ \pm} 6.91$ & $56.03_{ \pm} 8.44$ & 0.507 \\
\hline
\end{tabular}




\begin{tabular}{|l|l|l|l|l|l|}
\hline Height(cm) & $157.20_{ \pm} 4.59$ & $158.28_{ \pm} 5.23$ & $157.20_{ \pm} 2.59$ & $157.56_{ \pm} 4.28$ & 0.436 \\
\hline $\operatorname{Sex}(\mathrm{M} / \mathrm{F})$ & $8 / 32$ & $10 / 30$ & $13 / 27$ & $31 / 89$ & 0.438 \\
\hline
\end{tabular}

Mean \pm SD: mean \pm standard deviation; $n$ : number of cases.

Changes in HR and MAP are shown in Table 2, 3 and Figure 1.In all the three groups, there was a fall in HR from baseline after administration of the study drug till two minutes after induction. An increase in HR was observed in all the groups 1minute after intubation which came to baseline within 4 minutes after intubation. We observed a fall in MAP in all the three groups after administration of the study drug till 2 minutes after induction. We also observed an increase in MAP in all the three groups 1minute after intubation which returned to baseline within 3 minutes. There was no significant difference of MAP among the three groups over the stages considered in the present study.

Table - 2: Group-wise mean \pm SD of heart rate (HR) at different stages

\begin{tabular}{|c|c|c|c|c|c|c|c|}
\hline \multirow[t]{2}{*}{$\begin{array}{l}\text { Para- } \\
\text { meters }\end{array}$} & $\begin{array}{l}\text { Group I } \\
\text { (fentanyl } \\
2 \square \text { g/kg) }\end{array}$ & $\begin{array}{c}\text { Group II } \\
\text { (butorphanol } \\
20 \square \mathbf{g} / \mathbf{k g})\end{array}$ & $\begin{array}{c}\text { Group } \\
\text { III(butorphanol } \\
\mathbf{4 0} \square \mathbf{g} / \mathbf{k g})\end{array}$ & Total & \multirow[t]{2}{*}{ df } & \multirow[t]{2}{*}{$\begin{array}{l}\text { F- } \\
\text { value }\end{array}$} & \multirow[t]{2}{*}{$\begin{array}{l}\text { P- } \\
\text { value }\end{array}$} \\
\hline & Mean \pm SD & Mean \pm SD & Mean \pm SD & Mean \pm SD & & & \\
\hline Baseline HR & $\begin{array}{c}79.83 \pm 11 \\
21\end{array}$ & $86.00 \pm 16.17$ & $86.28 \pm 13.48$ & $\begin{array}{r}84.03 \pm 1 \\
3.98\end{array}$ & $(2,117)$ & 2.804 & 0.065 \\
\hline Drug HR & $\begin{array}{c}77.33 \pm 13 . \\
18\end{array}$ & $82.98 \pm 15.44$ & $83.58 \pm 10.20$ & $\begin{array}{r}81.29 \pm 1 \\
3.31 \\
\end{array}$ & $(2,117)$ & 2.763 & 0.067 \\
\hline I HR & $\begin{array}{c}74.85 \pm 12 . \\
42\end{array}$ & $78.03 \pm 12.05$ & $78.03 \pm 9.54$ & $\begin{array}{r}76.97 \pm 1 \\
1.41 \\
\end{array}$ & $(2,117)$ & 1.031 & 0.360 \\
\hline PI1 HR & $\begin{array}{l}74.30 \pm 9.9 \\
5\end{array}$ & $76.30 \pm 10.23$ & $77.43 \pm 9.61$ & $\begin{array}{l}76.01 \pm 9 . \\
94\end{array}$ & $(2,117)$ & 1.015 & 0.366 \\
\hline PI2HR & $\begin{array}{l}75.00 \pm 13 . \\
51\end{array}$ & $80.08 \pm 11.17$ & $80.28 \pm 9.55$ & $\begin{array}{r}78.45 \pm 1 \\
1.69 \\
\end{array}$ & $(2,117)$ & 2.689 & 0.072 \\
\hline PIX1HR & $\begin{array}{c}97.08 \pm 15 \\
45\end{array}$ & $99.35 \pm 12.43$ & $97.18 \pm 10.48$ & $\begin{array}{r}97.87 \pm 1 \\
2.88\end{array}$ & $(2,117)$ & 0.394 & 0.675 \\
\hline PIX2HR & $\begin{array}{c}90.70 \pm 14 \\
27\end{array}$ & $92.58 \pm 10.72$ & $91.65 \pm 9.64$ & $\begin{array}{r}91.64 \pm 1 \\
1.64\end{array}$ & $(2,117)$ & 0.256 & 0.775 \\
\hline PIX3HR & $\begin{array}{c}86.80 \pm 13 \\
31\end{array}$ & $87.08 \pm 10.78$ & $88.95 \pm 9.04$ & $\begin{array}{r}87.61 \pm 1 \\
1.13 \\
\end{array}$ & $(2,117)$ & 0.438 & 0.647 \\
\hline PIX4HR & $\begin{array}{c}84.03 \pm 12 . \\
95\end{array}$ & $82.78 \pm 10.21$ & $85.38 \pm 8.57$ & $\begin{array}{r}84.06 \pm 1 \\
0.69\end{array}$ & $(2,117)$ & 0.587 & 0.557 \\
\hline PIX5HR & $\begin{array}{c}82.03 \pm 11 \\
63\end{array}$ & $81.03 \pm 9.36$ & $82.98 \pm 9.56$ & $\begin{array}{r}82.01 \pm 1 \\
0.18\end{array}$ & $(2,117)$ & 0.363 & 0.696 \\
\hline
\end{tabular}

Mean \pm SD: mean \pm standard deviation; $n:$ number of cases; df: degree of freedom;

$F: A N O V A$ (analysis of variance ratio); P: probability of difference due to chance factors.

Table - 3Group-wise mean \pm SD of mean arterial pressure (MAP) at different stages

\begin{tabular}{|c|c|c|c|c|c|c|c|}
\hline \multirow[t]{2}{*}{$\begin{array}{l}\text { Parameter } \\
\text { s }\end{array}$} & $\begin{array}{l}\text { Group I } \\
\text { (fentanyl } \\
2 \square \text { g/kg) }\end{array}$ & $\begin{array}{l}\text { GroupII } \\
\text { (butorphanol } \\
20 \square \text { g/kg) }\end{array}$ & $\begin{array}{l}\text { GroupIII } \\
\text { (butorphano } \\
140 \square \mathrm{g} / \mathrm{kg} \text { ) }\end{array}$ & Total & df & $\begin{array}{l}\text { F- } \\
\text { value }\end{array}$ & $\begin{array}{l}\text { P- } \\
\text { value }\end{array}$ \\
\hline & Mean \pm SD & Mean \pm SD & Mean \pm SD & Mean \pm SD & & & \\
\hline $\begin{array}{l}\text { Baseline } \\
\text { MAP }\end{array}$ & $94.63 \pm 11.38$ & $96.70 \pm 9.44$ & $96.88 \pm 8.82$ & $\begin{array}{c}96.07 \pm 9.9 \\
1 \\
\end{array}$ & $(2,117)$ & $\begin{array}{r}0.6 \\
34 \\
\end{array}$ & 0.532 \\
\hline Drug MAP & $88.78 \pm 11.80$ & $91.90 \pm 10.33$ & $91.38 \pm 8.48$ & $\begin{array}{r}90.68 \pm 10 . \\
30 \\
\end{array}$ & $(2,117)$ & $\begin{array}{r}1.0 \\
56 \\
\end{array}$ & 0.351 \\
\hline I MAP & $83.73 \pm 9.29$ & $85.85 \pm 11.17$ & $84.75 \pm 8.73$ & $\begin{array}{l}84.78 \pm 9.7 \\
4\end{array}$ & $(2,117)$ & $\begin{array}{r}0.4 \\
71 \\
\end{array}$ & 0.626 \\
\hline PI1MAP & $84.93 \pm 13.28$ & $83.28 \pm 10.80$ & $81.68 \pm 8.24$ & $\begin{array}{r}83.29 \pm 10 . \\
96\end{array}$ & $(2,117)$ & $\begin{array}{c}0.8 \\
77\end{array}$ & 0.419 \\
\hline PI2MAP & $82.38 \pm 11.48$ & $86.10 \pm 11.13$ & $85.25 \pm 7.78$ & $\begin{array}{r}84.58 \pm 10 . \\
30\end{array}$ & $(2,117)$ & $\begin{array}{r}1.4 \\
45\end{array}$ & 0.240 \\
\hline $\begin{array}{l}\text { PIX1 } \\
\text { MAP }\end{array}$ & $107.08 \pm 11.72$ & $104.95 \pm 8.59$ & $\begin{array}{l}105.08 \pm 8.2 \\
7\end{array}$ & $\begin{array}{l}105.70 \pm 9 . \\
62\end{array}$ & $(2,117)$ & $\begin{array}{r}0.6 \\
10\end{array}$ & 0.545 \\
\hline $\begin{array}{l}\text { PIX2 } \\
\text { MAP }\end{array}$ & $95.88 \pm 10.09$ & $94.03 \pm 9.29$ & $97.80 \pm 8.32$ & $\begin{array}{c}95.90 \pm 9.3 \\
1\end{array}$ & $(2,117)$ & $\begin{array}{r}1.6 \\
60\end{array}$ & 0.195 \\
\hline $\begin{array}{l}\text { PIX3 } \\
\text { MAP }\end{array}$ & $90.58 \pm 10.39$ & $87.78 \pm 6.90$ & $91.15 \pm 7.97$ & $\begin{array}{c}89.83 \pm 8.6 \\
0\end{array}$ & $(2,117)$ & $\begin{array}{l}1.7 \\
83\end{array}$ & 0.173 \\
\hline PIX4 & $86.03 \pm 12.54$ & $84.58 \pm 7.31$ & $86.08 \pm 7.76$ & $85.56 \pm 9.4$ & & 0.3 & 0.726 \\
\hline
\end{tabular}


Effects Of Fentanyl And Butorphanol On Induction Dose Of Propofol In Adults

\begin{tabular}{|l|r|r|r|r|r|r|r|}
\hline MAP & & & & 5 & $(2,117)$ & 21 & \\
\hline PIX5 & $84.20 \pm 11.13$ & $83.28 \pm 9.55$ & $81.93 \pm 14.6$ & $83.13 \pm 11$. & & 0.3 & 0.694 \\
MAP & & 2 & 89 & $(2,117)$ & 66 & 0.694 \\
\hline
\end{tabular}

Mean \pm SD: mean \pm standard deviation; $n:$ number of cases; $d$ : degree of freedom;

$F$ : ANOVA (analysis of variance ratio); P: probability of difference due to chance factors.

Fig-1Group-wise trends of mean HR and MAP at different stages

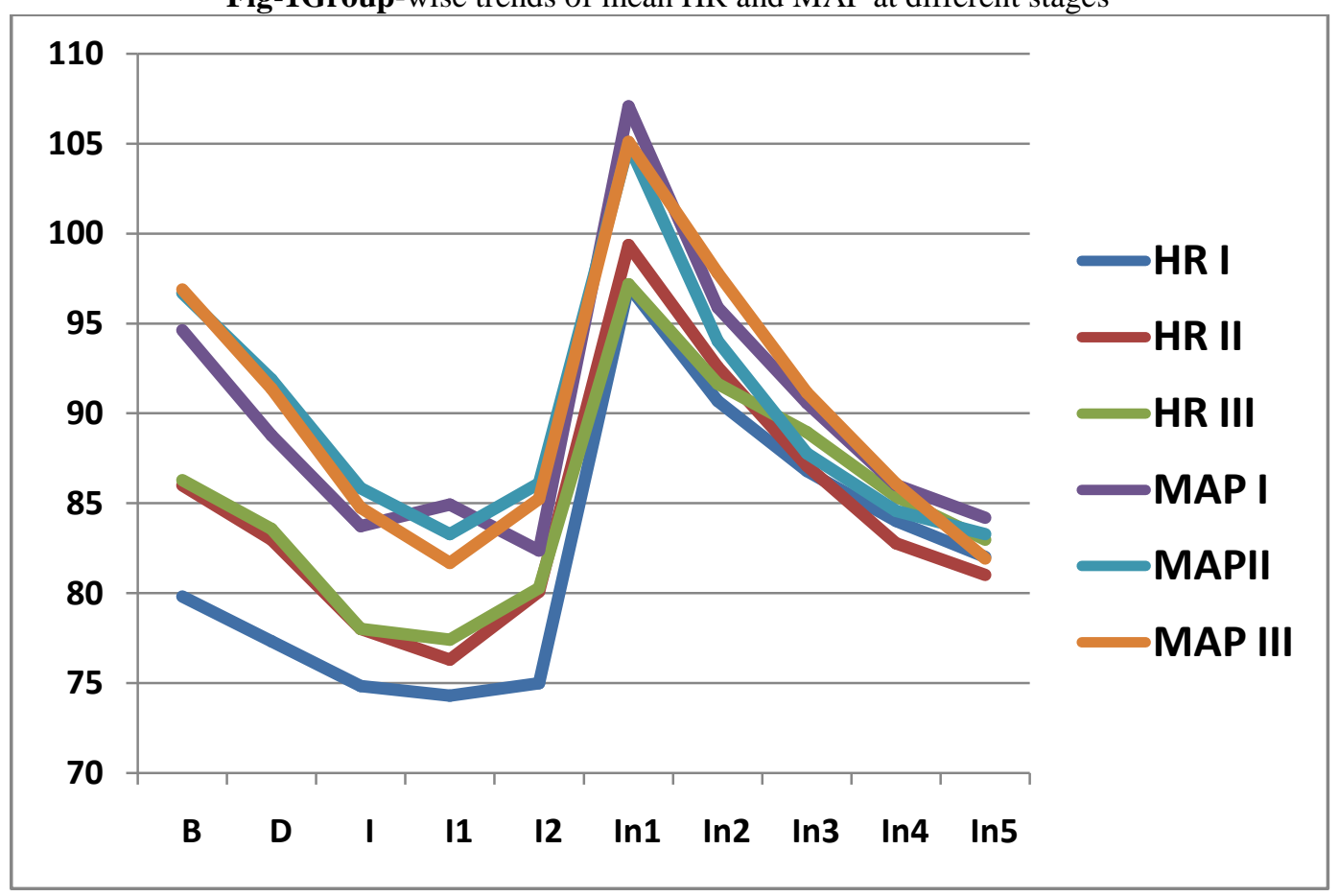

Table -4 :Group-wise mean \pm SD propofol dose

\begin{tabular}{|l|c|l|l|l|r|}
\hline Parameters & $\begin{array}{c}\text { GroupI } \\
\text { (fentanyl } \\
\mathbf{2} \square \mathbf{g} / \mathbf{k g} \text { ) }\end{array}$ & $\begin{array}{l}\text { GroupII } \\
\text { (butorphanol } \\
\mathbf{2 0} \square \mathbf{g} / \mathbf{k g} \text { ) }\end{array}$ & $\begin{array}{l}\text { GroupIII } \\
\text { (butorphanol } \\
\mathbf{4 0} \square \mathbf{g} / \mathbf{k g} \text { ) }\end{array}$ & $\begin{array}{l}\text { Total } \\
\mathbf{n}\end{array}$ & \multirow{2}{*}{ P-value } \\
\cline { 2 - 5 } & Mean \pm SD & Mean \pm SD & Mean \pm SD & \multicolumn{1}{|c|}{ Mean \pm SD } & \\
\hline $\begin{array}{l}\text { Propofol } \\
\text { dose(in mg) }\end{array}$ & $55.43 \pm 14.643$ & $53.63 \pm 7.16$ & $49.75 \pm 8.393$ & $52.93 \pm 10.76$ & 0.054 \\
\hline $\begin{array}{l}\text { Propofol } \\
\text { dose/weight } \\
\text { (mg/kg ) }\end{array}$ & $1.01 \pm .25$ & $0.95 \pm .18$ & $0.90 \pm .15$ & $0.95 \pm .20$ & 0.062 \\
\hline
\end{tabular}

Mean $\pm S D:$ mean \pm standard deviation; $n:$ number of cases

The propofol induction dose was comparable in all the three groups $(\mathrm{P}>0.05)$ as shown in table 2 .

Table-5: Group-wise adverse effect

\begin{tabular}{|c|c|c|c|c|}
\hline \multicolumn{2}{|r|}{ Parameters } & Group I & Group III & Total \\
\hline \multirow{4}{*}{ 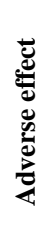 } & Cough & $1(25.0 \%)$ & - & $1(16.7 \%)$ \\
\hline & Dizziness & $2(50.0 \%)$ & $2(100.0 \%)$ & $4(66.7 \%)$ \\
\hline & Nausea & $1(25.0 \%)$ & - & $1(16.7 \%)$ \\
\hline & Total & $4(100.0 \%)$ & $2(100.0 \%)$ & $6(100.0 \%)$ \\
\hline
\end{tabular}

Due to most of theoretical cell frequencies are less than 5 , the test statistic especially $\chi^{2}$ could not be applied. 
No adverse effect was noticed in group-II. In group I, one patient complained of nausea, one patient complained of cough and two patients complained of dizziness. In group III, two patients complained of dizziness.(Table 5).

\section{Discussion}

In our present study, an attempt was made to assess the effect of equipotent doses of fentanyl $(2 \mu \mathrm{g} / \mathrm{kg})$ and butorphanol $(40 \mu \mathrm{g} / \mathrm{kg})$ in reducing propofol dose during induction of general anaesthesia. ${ }^{4}$ The administration of propofol combined with an opioidhas become a popular anaesthetic technique. It is generally agreed that the anaesthetic effect of propofol is enhanced by the additional administration of an opioid. Our study show that the induction dose of propofol is reduced with fentanyl $2 \mu \mathrm{g} / \mathrm{kg}$ and butorphanol at $20 \mu \mathrm{g} / \mathrm{kg}$ and 40 $\mu \mathrm{g} / \mathrm{kg}$ comparably. Haemodynamic parameters in all the three groups were also comparable. However, sedation was observed to a greater degree with butorphanol $40 \mu \mathrm{g} / \mathrm{kg}$. The reduction in propofol dose with butorphanol $20 \mu \mathrm{g} / \mathrm{kg}$ and fentanyl $2 \mu \mathrm{g} / \mathrm{kg}$ in our study wascomparable with Kaur $\mathbf{J}$ et $\mathrm{al}^{3}(0.95 \pm 0.18 \mathrm{mg} / \mathrm{kg}$ and $1.01 \pm 0.25 \mathrm{mg} / \mathrm{kg}$ vs $1.05 \pm 0.35 \mathrm{mg} / \mathrm{kg}$ and $1.1 \pm 0.50 \mathrm{mg} / \mathrm{kg})$. There was a difference in the propofol dose reduction with $40 \mu \mathrm{g} / \mathrm{kg}$ butorphanol in our study $(0.90 \pm 0.15 \mathrm{mg} / \mathrm{kg})$ when compared with Kaur J et al ${ }^{3}(1.05 \pm 0.35 \mathrm{mg} / \mathrm{kg})$, which might be due to the difference in the demographic profile. The concentration of propofol required for loss of consciousness is reduced by increasing fentanyl concentration. However a ceiling effect was seen with concentrations greater than $3 \mu \mathrm{g} / \mathrm{kg}^{5}$

Arora $\mathrm{V}$ et $\mathrm{al}^{15}$ demonstrated that the mean propofol consumption in fentanyl group $(2 \mu \mathrm{g} / \mathrm{kg})$ was slightly higher $(406.7 \pm 96.36 \mathrm{mg}$ ) as compared to butorphanol $40 \mu \mathrm{g} / \mathrm{kg}$ group $(380.5 \pm 92.4 \mathrm{mg})$. Lysakowski C et $\mathrm{al}^{6}$ showed in their study that in the presence of analgesic concentration of fentanyl, loss of consciousness occurred at a lower effect-site concentration of propofol. Pretreatment with fentanyl also potentiated the effect of propofol and hypnotic end points are achieved at lower propofol doses and concentrations. ${ }^{11}$

The administration of an induction dose of propofol produces a decrease in HR, systolic and diastolic blood pressure. In our study, the hypotensive response to an induction dose of propofol is reduced by decreasing the induction dose. We observed an increase in the HR, SBP, DBP and MAP in the post intubation period in all the three groups. Our findings are comparable to those observed by Kaur $\mathbf{J}$ et al. ${ }^{3}$ They found a comparable increase in HR in the post intubation period in all the three groups which returned to baseline within 5 minutes. Rao $\mathrm{MH}$ et al. ${ }^{16}$ observed in their study that there was a significant fall in HR and DBP in patients who received butorphanol as premedication as compared with those who received fentanyl in which there was rise in HR and BP intraoperatively. Higher fall in DBP was seen in butorphanol group than the fentanyl group. However, the rise in HR and BP were not upto $20 \%$ of preoperative value in fentanyl premedication which is in agreement with our findings. Philip BK et al $^{17}$ found in their study that patients who received butorphanol 20 $\mu \mathrm{g} / \mathrm{kg}$ prior to induction showed a lower heart rate before ( $79 \pm 14$ in butorphanol group vs. $89 \pm 15$ in fentanyl group) and after intubation ( $89 \pm 20$ in butorphanol group vs. $103 \pm 20$ in fentanyl group) and lower diastolic blood pressures after intubation in butorphanol group $(88 \pm 18 \mathrm{mmHg})$ as compared with fentanyl $1 \mu \mathrm{g} / \mathrm{kg}(101 \pm 17$ $\mathrm{mmHg})$.

Pandit SK et al ${ }^{14}$ found in his study that butorphanol $40 \mu \mathrm{g} / \mathrm{kg}$ gave better protection against autonomic stimulation to tracheal intubation as compared with fentanyl $2 \mu \mathrm{g} / \mathrm{kg}$. The only significant change occurred $2 \mathrm{~min}$ after tracheal intubation in the fentanyl group when both the heart rate and systolic blood pressure were significantly higher than the preoperative baseline values. However, apart from this, there was no other significant difference between butorphanol and fentanyl during either induction or maintenance of anaesthesia.

We also found that butorphanol $40 \mu \mathrm{g} / \mathrm{kg}$ produces more sedation compared to fentanyl $2 \mu \mathrm{g} / \mathrm{kg}$ and butorphanol $20 \mu \mathrm{g} / \mathrm{kg}$. Depth of sedation was assessed using modified OAA $/ \mathrm{S} .{ }^{13}$ Our findings are in concordance with Kaur $\mathrm{J}$ et $\mathrm{al}^{3}$ where higher sedation was observed with both butorphanol groups as compared with fentanyl. In our study, we observed a fall in respiratory rate and meanSpO $\mathrm{O}_{2}$ after administration of the study drugs in all the three groups. However, there was no significant difference among the three groups. Oxygen desaturation was seen in 2 patients (5\%) with fentanyl, 1 patient $(2.5 \%)$ with butorphanol $20 \mu \mathrm{g} / \mathrm{kg}$ and 4 patients $(10 \%)$ with butorphanol $40 \mu \mathrm{g} / \mathrm{kg}$. We also found in our study that fentanyl $2 \mu \mathrm{g} / \mathrm{kg}$ was associated with cough in 1 patient, nausea in 1 patient and dizziness in 2 patients. Butorphanol $40 \mu \mathrm{g} / \mathrm{kg}$ was also associated with dizziness in 2 cases.Kaur $\mathrm{J}$ et $\mathrm{al}^{3}$ did not report any patient complaining of nausea or vomiting after administration of the study drug. However 3 patients (7.5\%) in fentanyl group and 1 patient $(2.5 \%)$ in butorphanol $20 \mu \mathrm{g} / \mathrm{kg}$ group had mild itching.Our study has several limitations. First, no control group was studied. The incidence of cardiorespiratory depression is higher with propofol as compared to other induction agents. Induction with propofol alone will cause a significant fall in the blood pressure. Secondly, we concluded our study five minutes after intubation. A comparison of haemodynamic parameters intraoperatively would have given a better idea about the effect of the study drugs on maintaining haemodynamic stability .Third; it needs to be assessed in varied ASA status. Fourth, different dose of fentanyl needs to be evaluated. 


\section{Conclusion}

It may be concluded that butorphanol in the twodifferent doses, reduced the induction dose of propofol comparable to fentanyl with stable hemodynamics during induction and intubation. However butorphanol $40 \mu \mathrm{g} / \mathrm{kg}$ was associated with more sedation.

\section{References}

[1]. Kanto JH. Propofol, the newest induction agent of anaesthesia. IntI J ClinPharmacolTherToxicol. 1988 Jan;26(1):41-57.

[2]. Sebel PS, Lowdon JD. Propofol: A new intravenous anaesthetic. Anaesthesiology. 1989;71:260-77.

[3]. Kaur J, Srilata M, Padmaja D, Gopinath R, Bajwa SJ, Kenneth J et al. Dose sparing of propofol by fentanyl and butorphanol: A comparison based on entropy analysis. Saudi J Anaesth. 2013 Apr- Jun; 7(2): 128-33.

[4]. Djordjevic B, Stojilikovic MP, Loncar-Stojilikovic D, Krivokapic D. Cardiovascular effects of induction doses of the intravenous anaesthetics, propofol, etomidate and thiopentone. Vojnosanit Pregl, 1999 Jan- Feb;56(1):15-9.

[5]. Smith C, Mc Ewan Al, Jhaveri R, Wilkinson M, Goodman D, Smith LR et al. The interaction of fentanyl on the Cp50 of propofol for loss of consciousness and skin incision. Anaesthesiology. 1994 Oct;81(4):820-8.

[6]. Lysakowski C, Dumont L, Pellegrini M, ClergueF, Tassonyi E. Effects of fentanyl, alfentanil, remifentanil and sufentanil on loss of consciousness and bispectral index during propofol induction of anaesthesia. Br J Anaesth 2001;86:523-7.

[7]. Reves J.G., Peter S.A. Glass, David A. Lumbarsky, Matthew D. McEvoy, Ricardo Martinez-Ruiz, intravenous anaesthetics. In: Miller RD, Eriksson LI, Fleisher LA, Wiener-Kronish JP, Young WL, editors.Miller's Anaesthesia. $7^{\text {th }}$ ed. New York , Churchill Livingstone; 2009. p.720-8.

[8]. Kazama T, Ikeda K, Morita K. The pharmacodynamic interaction between propofol and fentanyl with respect to the suppression of somatic or haemodynamic responses to skin incision, peritoneum incision, and abdominal wall retraction. Anaesthesiology. 1988 Oct;89(4): 894-906.

[9]. Commiskey S, Fan LW, Ho IK, Rockhold RW. Butorphanol: effects of a prototypical agonist-antagonist analgesic on kappa-opioid receptors. J . Pharmacol Sci. 2005 Jun;98(2):109-16.

[10]. Tsuchida H, Seki S, Iwasaki H, Kumeta Y, Namiki A. Comparison of adjuvant anaesthetics for propofol induction. J Anaesth. 2003;17(3):154-60.

[11]. Mi WD, Sakai T, Takahashi S, Matsuki A. Haemodynamic and electroencephalograph responses to intubation during induction with propofol or propofol/fentanyl. Can J Anaesth. 1998 Jan;45(1):19-22.

[12]. Walker R.ASA and CEPOD scoring. Update in Anaesthesia.2002;(14):1

[13]. Chernic DA, Gilling D, Laine H, Hendler J, Silver JM, Davidson AB, et al. Validity and reliability of the observer,s assessment of alertness/sedation scale: Study with intravenous midazolam. J ClinPsychopharmacol. 1990;10:244-51.

[14]. Pandit SK, Kothary SP, Pandit UA, Mathai MK. Comparison of fentanyl and butorphanol for outpatient anaesthesia. Can J Anaesth. 1987 Mar;34(2):130-4.

[15]. Arora V, Bajwa SJ, Kaur S. Comparative evaluation of recovery characteristics of fentanyl and butorphanol when used as supplement to propofol anaesthesia. Int J Appl Basic Med Res. 2012 Jul;2(2):97-101.

[16]. Rao MH, Satyanarayana V, Srinivas B, Muralidhar A, Samantaray A, Reddy AS et al. Comparison of butorphanol and fentanyl for balanced anaesthesia in patients undergoing laparoscopic surgeries under general anaesthesia: A prospective, randomized and double blind study. J Clin Sci Res 2013;2:8-15.

[17]. Philip BK, Scott DA, Freiberger D, Gibbs RR, Hunt C, Murray E. Butorphanol compared with fentanyl in general anaesthesia for ambulatory laparoscopy. Can J Anaesth. 1991 Mar;38(2):183-6. 